\title{
Research on the Coordination Nature between Community Culture Construction and Universities Music Education
}

\author{
Zhang Junping \\ Leshan Normal University music institute \\ Leshan ,Sichuan 614000,China
}

\begin{abstract}
Community culture is an important part of our traditional culture, and it is the culture atmosphere of existence, development and practice for college music education activities. On the basis of years of study and practice, this paper analyzes the docking role of community cultural development and music education, and then studys the integration feasibility of community cultural development with music education, finally, this paper works out the integration strategies of community cultural development and university music education. The research results have a certain reference significance for the development of community cultural and music education in universities.
\end{abstract}

Keywords- community cultural development; music education in universities; resource sharing

\section{DOCKING EFFECT OF COMMUNITY CULTURAL DEVELOPMENT AND UNIVERSITY MUSIC EDUCATION}

\section{A. To achieve innovation and tradition for the community culture}

Chinese community cultural heritage is mostly achieved by ordinary people through seen and heard, words and deeds ways, which both lacks text-based teaching materials, but also no systematic, rigorous teaching methods, especially a lot of folk culture, folk art is also facing an embarrassing plight of no heir, resulting in serious loss of community culture. As a cultural and educational institutions, colleges and universities have a responsibility and more power to innovative community cultural style, so that it can adapt to the new era of the environment, to meet the aesthetic needs of people, thus achieving widespread community cultural and historical heritage.

\section{B. To create a good community cultural atmosphere}

In recent years, with the development of society, on one hand governments are increasingly focused on improving cultural enrichment, moral qualities of the people to create a good image in the region, on the other hand, after people get great satisfaction in material life, they also require a higher level of spiritual appetite, resulting in the healthy development of the physical, psychological, emotional, intellectual. Music education in universities activities strengthen mining and dissemination for community culture, in particular, hold a variety of musical performances in a specific area, which just be able to create a good community culture, and this not only enhance people's musicianship, stimulate their desire to learn music and music performances, but also create a good image of the region, thus bringing more added value for regional development.

\section{To enrich the content of university music teaching}

Music teaching content of Chinese universities includes music basics, music appreciation and music practice, thus to enrich students' music knowledge, strengthen their music sense, and enhance the music practice of acting ability. However, through in-depth analysis of the teaching content, we find music education focuses on basic musical knowledge and popular music art, such as "music theory based tutorial", "knowledge of music and music appreciation," "Chorus and conductor", rarely involves attention to a small minority community culture. However, our community culture contains a wealth of musical material. According to "China Intangible Cultural Heritage", Henan province has a total of 26 kinds of folk music forms. Almost every region has a unique folk music art, and each university itself exists in a particular community cultural atmosphere, being familiar with the musical structure of folk music, singing skills, cultural connotation and aesthetic implication shows a strong psychological affinity. Therefore, to enhance the docking between music education and community cultural construction can greatly enrich the content of colleges music education.

\section{To innovative music education mode}

Innovative teaching mode is an important channel for improving the quality of teaching. To some extent, the docking with the community cultural development can greatly enhance music education activities to innovate the current music teaching mode. First, after the completion of the basic music theory taught activities, college music teachers can encourage students to further go to real life, active exploration to mine communities valuable musical material culture, including folk music, art, rap art, folk tales, and then do a certain consolidation to form their own music, at last we put the work to be performed in the classroom, and teachers and students need to give some reviews. This not only can enhance students' practical music ability to stimulate their interest in learning, but also can find their own inadequacies and problems in a timely manner, thereby to correct this as soon as possible. This teaching activities from classroom to classroom life and then teaching mode is different from traditional classroom, showing a higher value and quality of teaching personnel training. 


\section{THE INTEGRATION FEASIBILITY OF COMMUNITY CULTURAL CONSTRUCTION AND MUSIC EDUCATION}

In recent years, with the growing enrollment of music professional, graduate student employment faces fierce competitive pressures, how to update the content of the music teaching and to innovate music teaching mode and teaching methods has become an important way for university culture to adapt to the needs of each of the music majors with strong competitiveness. University music faculty and students master a profound knowledge of music theory and music capabilities, showing a high level of musical appreciation. Thus, on the one hand, they are able to discover valuable community cultural music clips and even music, further to record and trim through professional musical knowledge for related music material, thus become an important part of classroom education; On the other hand it is possible to enjoy the musical characteristics according to the local population, to create all kinds of music, musical evenings, etc., thus creating good music culture. This provides a technical guarantee for the docking of music education with the community culture.

\section{INTEGRATION STRATEGIES OF COMMUNITY CULTURAL CONSTRUCTION AND UNIVERSITY MUSIC EDUCATION}

\section{A. Clear community cultural characteristics}

In the long history the development process, each region has a unique cultural styles, including music, dance, song, costumes, architecture and customs and so on. This is the most valuable elements of culture, but hidden in every corner of society, therefore, to build community among cultures through music education activities, there must be a way through field visits for local community culture of a systematic and comprehensive investigation and understanding, a clear community cultural content and cultural features, thus laying the foundation of music education for future activities at the core of community cultural transmission.

\section{B. Focus on social demand characteristics}

Currently, the demand for community culture is mainly reflected in two aspects: First, the local people have their own music and appreciation of aesthetic features characteristic; Second, the government departments in various regions are also mostly developed a clear community cultural development goals and development plans, or is to create an image of the historic and cultural city, or to create a modern urban fashion sense, also, or showing a natural ecocity and so on. In this case, all cultural activities must be expanded as a center, in order to obtain maximum support by the government. Therefore, the docking between university music education and community cultural construction should fully take the general public, government agencies, the demand for urban culture into account in order to achieve the cultural value construction, especially to achieve the traditional culture heritage and development.

\section{Build a smooth integration channel}

After clear community cultural characteristics and different subjects demand for community culture, the next step is going to construct a smooth docking channels. First, after the completing the basic knowledge explanation, teachers can introduce community cultural development, community cultural transmission as the core values and methods and techniques important music events for music students, then encourage students to dig musical material in a specific area of daily life, making it into a complete piece of music and get it in the classroom to provide teachers and other students to appreciate and comment. This approach not only allows students to clear the importance of community culture construction, and be aware of the community culture inherent in the rich musical material, but also to achieve the community's innovative culture and heritage through the student musical composition. Second, teachers can also be deep social life, recorded musical works and music material having value, on the one hand, the work is to get in the classroom, as lectures to stimulate student interest in community culture, thereby strengthening research activities in this area, on the other hand, the work can also produce music with a strong geographical and cultural characteristics, and then it is sold to some record company or a singer, thereby enabling the spread of the community culture. Third, the Music Academy in institutions of higher learning should put some manpower, material and financial resources to build and disseminate community culture, for example, employing folk artists as a teacher to teach folk music and folk songs, or offering folk music courses, and this can form a strong community atmosphere of cultural studies and communication throughout the school. Fourth, for conservatory in universities, on one hand, some music concert, musical competitions organized by their interior should be extended to outside for the general public to participate in a music appreciation or even a chance to inspire their music appreciation, stimulating their music appreciation, interest in learning music and music performances and improving music literacy, but also be able to create a good community culture. On the other hand, they should actively participate in various cultural activities in the city, including the festival activities, commercial activities, through professional music teachers, music students in terms of expertise, community cultural can enrich the arts programs, improve the quality of cultural programs, providing high-quality community, a high level of artistic performances. Fifth, the various local government departments, universities institution shall establish a task items around the docking urban culture and music education, and encourage more experts and scholars in this research activities to provide some guidance and reference value for docking of music education and urban culture.

\section{Realize the value of the integration work}

Music education and urban cultural construction docking process is bound to produce a series of docking works, including music, song and even the musical works and other works. We must implement the spread and economic value of docking works, and various works should be consolidated 
to spread out for more people to enjoy, getting some economic return in the process. This not only able to give students some psychological satisfaction and sense of accomplishment, inspire passions of student to research and disseminate community culture, but also provide some funding for related music, music events, music educatio, which can ensure the smooth implementation of the docking project between music education and community cultural development.

\section{CONCLUSION}

Community culture development is related to innovation and heritage of traditional culture, and it is a social project benefitting the country. As a culture media organizations, college music education sector has the ability and responsibility to the community culture research, innovation and construction activities. In this process, it is necessary to define the characteristics and features of a particular social needs of the community culture, at the same time, it needs to take appropriate integration channels in order to ensure the smooth integration of music education and community culture.

\section{ACKNOWLEDGEMENT}

Support the project: research project of Sichuan Provincial Department of education funding 《research on
Strategy of sharing local college music education resources with local community arts and cultural construction》 Project No. $13 \mathrm{SB} 0146$

\section{References}

[1] Antti Juvonen, Heikki Ruismäki,Kimmo Lehtonen. Music Education Facing New Challenges[J]. Procedia - Social and Behavioral Sciences, 2012,45:

[2] Ayşen Arslan. Classroom teacher candidates' efficiency on the music culture and their music preferences[J]. Procedia - Social and Behavioral Sciences, 2010,22:

[3] Wai-Chung Ho,Wing-Wah Law. Students' music experiences, society and culture: music education in Shanghai, China[J]. Music Education Research,2006,81:

[4] AFA Owner Rethinking Turkish Music School' Administrative Model in the Context of Music Education Culture: Is there a Need for an Educational Leadership Model?[J]. Procedia - Social and Behavioral Sciences,2014,116:.

[5] Rory Crutchfield. If Beale Street Could Talk: Music, Community, Culture[J]. Popular Music,2012,31:.

[6] Robert A. Davis. Music Education and Cultural Identity[J]. Educational Philosophy and Theory,2005,371:. 